\title{
USE OF ECOLOGICAL NICHE MODELS OF PLANT SPECIES TO OPTIMIZE PLACEMENT OF APIARIES
}

\author{
Yareli J. Cadena Rodríguez ${ }^{1 *}$ \\ Monserrat Vázquez-Sánchez² \\ Gustavo Cruz-Cárdenas ${ }^{1}$ \\ José L. Villaseñor ${ }^{3}$ \\ ${ }^{1}$ Instituto Politécnico Nacional, Centro Interdisciplinario de Investigación para el \\ Desarrollo Integral Regional (CIIDIR), Unidad Michoacán, COFAA, Justo Sierra 28. C. P. \\ 59510. Jiquilpan, Michoacán \\ 2Colegio de Postgraduados, Campus Montecillo, Carr. México-Texcoco Km 36.5, \\ 56230 Texcoco, Estado de México, México \\ IInstituto de Biología, Universidad Nacional Autónoma de México, Departamento de \\ Botanica, Apartado Postal 70-233, C.P. 04510, CDMX. Mexico \\ *corresponding author: cryj_20@hotmail.com \\ Received: 12 October 2018; accepted: 15 April 2019
}

A bstract

Apiaries must be located in areas with abundant flora as they are the nutritional base for Apis mellifera. Asteraceae is one of the most diverse plant families in Mexico and several of its species are of interest for beekeepers. The objective of this study was to determine the best sites for the placement of apiaries with the use of ecological niche models (ENM) of some Asteraceae species important for bees in two basins of the state of Michoacán, Mexico. ENM for thirty species were obtained through records of their presence, twenty abiotic variables and one biotic variable, and a map of species richness was made to determine which sites would be environmentally appropriate for apiaries. The models were statistically evaluated using the AUC_Maxent, partial_ROC and the binomial tests and were verified in the field. The first two tests' models had values of 0.70 to 1 and the binomial test's models had values of 1 . The map showed six suitable areas with the greatest richness of species. The corroboration in the field proved ENM effective by finding twenty-two of the thirty modeled species inside the predicted areas. Our results support that ENM are a good strategy to predict the ideal habitat for species important for beekeeping, and thus determine the best places to establish apiaries in the region.

Keywords: Apis mellifera, assemblage of species, Maxent, Mexico, Nectariferouspolliniferous flora

\section{INTRODUCTION}

Beekeeping is the agricultural activity of breeding honey bees (Apis mellifera L.) and installing apiaries to obtain honey and other derivatives (Bradbear, 2005; Barrios et al., 2012). In addition to honey production, bees provide important ecosystem services, especially in agriculture and pollination (FAO, 2014, Verde, 2014). According to the Mexican Agricultural and Fisheries Information Service (SIAP, 2015), approximately 1.5 million tons of honey are produced per year worldwide. China is the largest producer, exporting around 400 tons of honey per year, while Mexico is located between the seventh and tenth place exporting around fifty tons of honey per year (FAO, 2017; Jegede, 2019). Knowledge of regional bee flora is important worldwide for beekeeping, and for good honey production strategies apiary management should be based on the availability of plant species that bees feed on (FAO, 2014; Verde, 2014; SAGARPA, 2011, 2011a, 2015, 2015a).

Mexico has approximately 22,126 flowering plant species (Villaseñor, 2016), ranking fourth in the world. According to palynological studies and bee floras of certain regions of the country, approximately 2,000 species are commonly visited by $A$. mellifera (de la Mora-González, 
1988; Santana-Michel et al., 1998; VillegasDurán et al., 1999, 2000, 2003; Bello-González, 2007; Piedras-Gutiérrez \& Quiroz-García, 2007; Quiroz-García \& Arreguín-Sánchez, 2008; Porter-Bolla et al., 2009; Villanueva-Gutierrez et al., 2009; Cordova-Cordova, 2009; Montoy-Koh, 2010; Ramírez-Arriaga et al., 2011; AcostaCastellanos et al., 2011; Galarza-Mendoza et al., 2012; Ramírez-Arriaga et al., 2016; GonzálezSandoval et al., 2016). The state of Michoacán in western Mexico records about 6,000 species of flowering plants (Villaseñor, 2016) and at least 237 of them are considered important for beekeeping (Villegas-Durán et al., 1999; Bello-González, 2007). Although Michoacán contains abundant and diverse flora, its honey production is low compared to other states. The state occupies tenth place with almost 2,000 tons of honey per year, whereas Jalisco, its neighboring state, places third with 7,000 tons. Although both states contain similar floristic richness, there is a large difference in their honey production possibly due to inadequate placement of apiaries. Manuals on the improvement of honey production mention that apiaries should be placed near bee flora and the difficulty beekeepers have in finding the right flora. Therefore, new strategies or tools that aid in finding new apiary sites with an abundant bee flora would help to increase honey production in Michoacán as well as other regions.

Ecological niche models (ENM) can be a useful tool to address the problem of apiary location. ENM considers the combination of biotic and abiotic ecological conditions that a species can tolerate in a multidimensional space (Soberón, 2007, 2010; Peterson et al., 2011). Maximum entropy used by Maxent software is one of the best-performing mathematical algorithms used to generate ENM (Elith et al., 2006, Elith \& Leathwick 2009; Phillips et al., 2006; NavarroCerrillo et al., 2011). Theoretically, ENM could help to locate the ideal conditions for plant species important for beekeeping and therefore improve the location of apiaries. ENM have been used for estimating floristic richness patterns (Villaseñor et al., 2013; Alvarado-Cárdenas et al., 2017), designing sampling methods for rare or little-known species (Gil \& Lobo, 2012), evaluating the impact of land use changes on threatened species and proposed conservation sites (Sánchez-Cordero et al., 2005; Peterson et al., 2006; Yáñez-Arenas et al., 2012), predicting species' potential future distribution under climate change scenarios (Lane \& Jarvis, 2007; Feria-Arroyo et al., 2013; Cruz-Cárdenas et al., 2016; Estrada et al., 2016) and delimiting the potential distribution of invasive species (PalmaOrdaz \& Delgadillo-Rodríguez, 2014). In relation to beekeeping, ENM have been used to estimate the distribution of bees in growing areas (Polce et al., 2013). The question addressed in this work is whether ENM can help determine suitable sites for the location of apiaries based on the plant species that $A$. mellifera feeds on. We considered the Asteraceae species to be one of the plant families visited most frequently by Apis mellifera. In Mexico at least 147 Asteraceae species have reported important for beekeeping (Piedras-Gutiérrez \& Quiroz-García, 2007; Quiroz-García \& Arreguín-Sánchez, 2008; Castellanos-Potenciano et al., 2012; Nates-Parra et al., 2013).

The assumption that underlies this research is that because Asteraceae species are among the most visited by $A$. mellifera, we can determine sites of species richness by modeling the ecological niches of Asteraceae species important for beekeeping and thereby pinpointing locations environmentally suitable for the establishment of apiaries. In order to evaluate our assumption, we selected the Asteraceae species most important for beekeeping in the study area, generated abiotic and biotic variables, elaborated ENM for the selected species, identified the contribution of the abiotic and biotic variables in the ENM species of the family, validated the models statistically and in the field, and determined which areas were environmentally suitable to find most of these species in the field.

\section{MATERIAL AND METHODS}

Area of study and selection of plant species The study area consists of two hydrologi- 
cal basins in the western Mexican state of Michoacán: Lake Chapala and the Duero River Basin (Fig. 1). Both basins belong to one of the most important hydrographic regions in Mexico, the Lerma-Santiago region, which begins in central Mexico (State of Mexico) and runs west to Michoacán and Jalisco. The Lake Chapala basin covers about $4,715 \mathrm{~km}^{2}$ and is delimited by the coordinates $20^{\circ} 22^{\prime}$ North, $19^{\circ} 50^{\prime}$ South, $102^{\circ} 21$ East and $103^{\circ} 34^{\prime}$ West. On the other hand, the Duero River basin has an approximate area of 2,661 $\mathrm{km}^{2}$, delimited by the coordinates $19^{\circ} 40^{\prime}$ North, $20^{\circ} 15^{\prime}$ South, $101^{\circ} 45^{\prime}$ East and $102^{\circ} 45^{\prime}$ West. The two basins together include fiftythree municipalities (Appendix 1).

The Asteraceae species were selected according to whether the species are distributed in the study area (Chapala-Duero basins), they are reported in the bee flora of Michoacán (VillegasDurán et al., 1999), honey bee pollen inventories or related floras and there are at least five records (Phillips et al., 2006) to generate the ENM. The search for specimens documenting the species was conducted in the National Herbarium of Mexico (MEXU) in Mexico City, Herbarium of the Interdisciplinary Research
Center for Regional Integral Development (CIMI) in Jiquilpan, Michoacán and Herbarium of the Institute of Ecology (IEB) in Pátzcuaro, Michoacán.

\section{Processing of presence records}

With the data obtained of the selected species, a database of thirty species was constructed with a total of 286 records for the study area. Each species had 5 to 40 records (Tab. 1). Only species with at least five records, the minimum number recommended to construct ENM (van Proosdij et al., 2006) were included in the study.

\section{Generation of abiotic variables}

Data for monthly minimum and maximum temperatures and precipitation between 1961 and 2016 were obtained from ninety-eight climatological stations of the Mexican National Meteorological Service (http://smn.cna.gob.mx/es/climatologia/informacion-climatologica) generated by the Mexican National Water Commission. In addition, 195 geographical data were used with such soil properties (INEGI, 2006; Cruz-Cárdenas et al., 2014b) as electrical conductivity, pH and organic matter. A geostatistical analysis

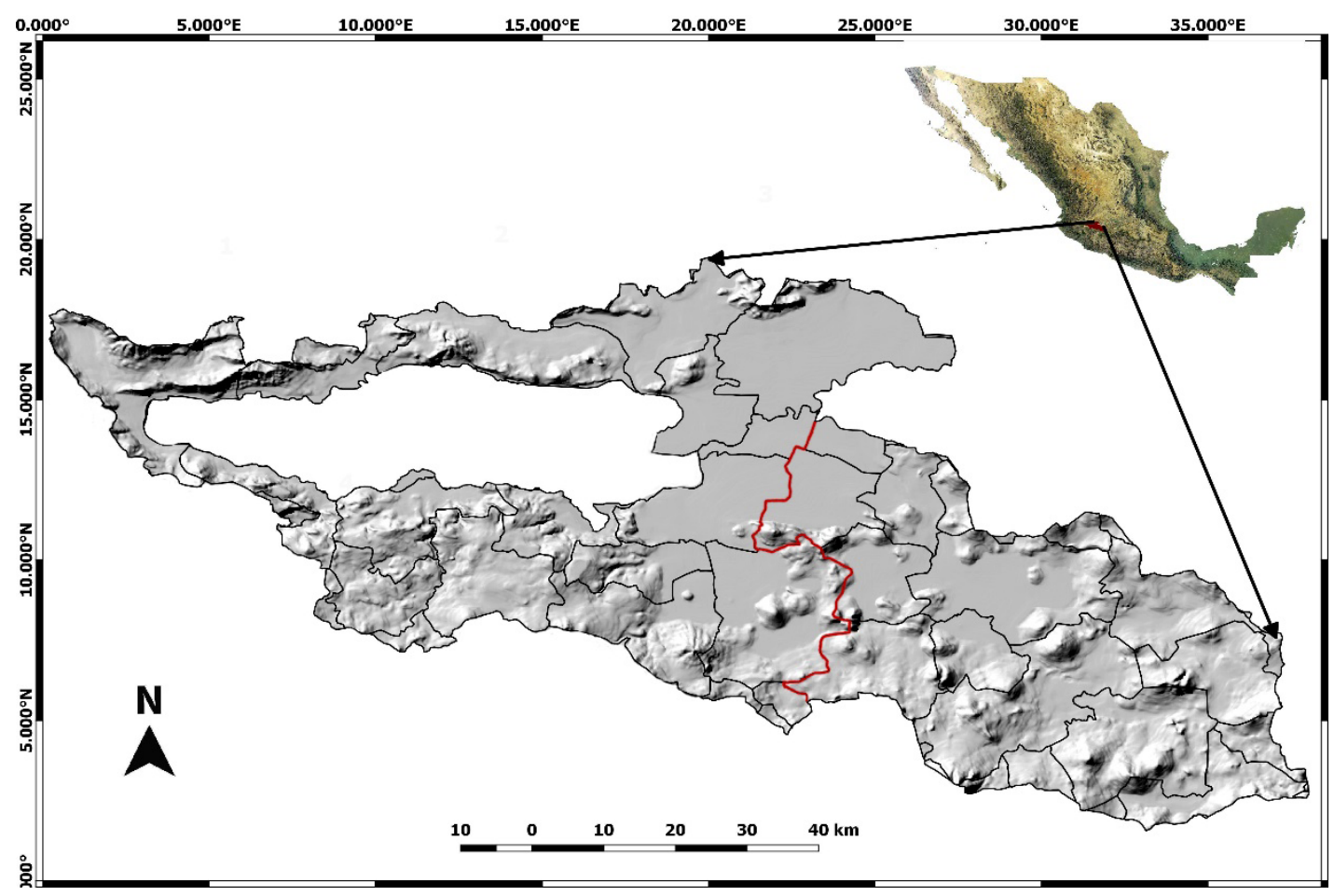

Fig. 1. Delimitation of the study area (Chapala and Duero River Basin).

The red line divides the municipalities corresponding to each basin. 
Table 1.

Asteraceae species of beekeeping interest selected for the study area. The number of records upon which ecological niche models (ENM) were based are shown, with the number of new records collected during fieldwork indicated in parentheses. Values from statistical evaluation of each ENM are also given

\begin{tabular}{|c|c|c|c|}
\hline Species & $\begin{array}{l}\text { Number of } \\
\text { records }\end{array}$ & $\begin{array}{c}\text { AUC } \\
\text { Maxent }\end{array}$ & $\begin{array}{l}\text { Average AUC } \\
\text { of partial Roc }\end{array}$ \\
\hline Acmella repens (Walter) Rich. & $9(1)$ & 0.93 & 1 \\
\hline Ageratina mairetiana (DC.) R.M. King \& H. Rob. var. mairetiana & 6 & 0.7 & 1 \\
\hline Ageratum corymbosum Zuccagni & $13(2)$ & 0.87 & 0.98 \\
\hline Aldama dentata La Llave & $11(8)$ & 0.93 & 1 \\
\hline Ambrosia peruviana Willd. & $11(3)$ & 0.83 & 0.99 \\
\hline Astranthium orthopodum (B.L. Rob. \& Fernald) Larsen & 8 & 0.86 & 1 \\
\hline Baccharis heterophylla Kunth & $9(1)$ & 0.89 & 1 \\
\hline Baccharis salicifolia (Ruiz \& Pav.) Pers. subsp. salicifolia & $8(5)$ & 0.92 & 1 \\
\hline Barkleyanthus salicifolius (Kunth) H. Rob. \& Brettell & $21(4)$ & 0.77 & 0.99 \\
\hline Bidens aequisquama (Fernald) Sherff var. aequisquama & $12(4)$ & 0.74 & 1 \\
\hline Bidens aurea (Aiton) Sherff & 5 & 0.76 & 1 \\
\hline Bidens odorata Cav. var. odorata & $5(1)$ & 0.86 & 1 \\
\hline Cosmos bipinnatus Cav. & $5(4)$ & 0.9 & 1 \\
\hline Cosmos sulphureus Cav. & $5(2)$ & 0.83 & 1 \\
\hline Dahlia coccinea Cav. & $12(2)$ & 0.89 & 1.01 \\
\hline Erigeron longipes DC. & $7(1)$ & 0.82 & 1 \\
\hline Galinsoga parviflora Cav. & $9(12)$ & 0.85 & 1 \\
\hline Guardiola mexicana Humb. \& Bonpl. var. mexicana & 5 & 0.70 & 1 \\
\hline Melampodium divaricatum (Rich.) DC. & $40(12)$ & 0.87 & 0.98 \\
\hline Melampodium perfoliatum (Cav.) Kunth & $10(8)$ & 0.95 & 1 \\
\hline Parthenium hysterophorus L. & $5(1)$ & 0.91 & 1 \\
\hline Pittocaulon velatum (Greenm.) H. Rob. \& Brettell var. velatum & 5 & 0.95 & 1 \\
\hline Pluchea carolinensis (Jacq.) G. Don & 6 & 0.65 & 1.01 \\
\hline Pluchea salicifolia (Mill.) S.F. Blake & $6(1)$ & 0.78 & 1 \\
\hline Tagetes erecta L. & $10(5)$ & 0.84 & 1 \\
\hline Tagetes filifolia Lag. & $7(3)$ & 0.86 & 1 \\
\hline Tithonia tubiformis (Jacq.) Cass. & $8(12)$ & 0.79 & 1 \\
\hline Verbesina sphaerocephala A. Gray & $15(8)$ & 0.87 & 1 \\
\hline Vernonia alamanii DC. & $7(3)$ & 0.84 & 1.03 \\
\hline Viguiera dentata (Cav.) Spreng. & 5 & 0.84 & 1.15 \\
\hline
\end{tabular}

(Goovaerts, 1999) of the climate and soil data was applied, and its first step consisted of data exploration and transformation with the use of the natural logarithm to adjust the data to a normal distribution. A structural analysis was then carried out and experimental variograms were elaborated for calculating the semi-variance $(y)$ of the data with the following formula (1):

$$
\text { (1) } \gamma(\mathrm{h})=\frac{1}{2} \mathrm{n} \sum_{\mathrm{i}=1}^{\mathrm{n}}[\mathrm{Z}(\mathrm{xi}+\mathrm{h})-\mathrm{Z}(\mathrm{xi})] 2
$$

The semi-variance of all the samples is within a particular space, separated by a distance $(h)$; $n$ is the total number of sample pairs; $Z(x)$ are the sampled locality climatic and soil values; and $Z\left(x_{i}+h\right)$ are the sampled locality values to the $h$ interval distance. The experimental variogram was adjusted to a linear model that recorded 
the minimum sum of squares error (SSE) for each dependent variable (Gallardo, 2006). Then, the spatial prediction after the adjustment of the experimental variogram was inferred using universal Kriging, as indicated by the cross-validation test, for climate and soil data. On the other hand, the climate variables were imported to DIVA-GIS 7.5 (DIVA-GIS, 2016) to generate five bioclimatic variables. In addition, four climatic seasonality variables and three evapotranspiration variables were produced. To generate the evapotranspiration variables, Turc's model was applied (Turc, 1954) as explained in Cruz-Cárdenas et al. (2014a). The continuous Mexican elevation model of INEGI (2017) was used to generate three topographic variables. In addition, remote sensing data were downloaded from the Landsat L8 satellite OLI / TIRS C1 Level -1 (Earth Explorer) over a period of one year (July 2016 to July 2017) using the scenes path 28, row 46 and path 29, row 46. Twelve mosaics of bands 4 (red) and 5 (infrared) were used to generate standard vegetation indexes for each mosaic applying the formula proposed by Manrique (1999), where NIR = near infrared band and $R E D=$ red band. SubsequentIy, the Normalized Vegetation Index (NDVI) for each mosaic was generated using this formula (2) proposed by Manrique (1999):

\section{(2) $N D V I=(N I R-R E D) /(N I R+R E D)$}

For the generated variables, a pixel size of $1 \mathrm{~km}^{2}$ was taken at a resolution of 0.008333 calculated with the following formula (3) proposed by Hengl (2006):

(3) Resolution and adequate pixel size $=\leq 0.05$ $* \sqrt{A} / N$,

where $A$ is the area in $\mathrm{km}^{2}$ (the size of the area is $57,948 \mathrm{~km}^{2}$ ) and $N$ is the sample size. For climatic data, $\mathrm{N}$ was the total climatic stations (98), and for the soil properties data $\mathrm{N}$ was the total sampling points (195).

Finally, a principal components analysis (PCA) was applied to the climate, seasonality climatic, soil, topography, and normalized vegetation index variables (Tab. 2), in order to reduce the correlation and the dimension of the variables. The components that cumulatively explained $95 \%$ of the variance of the original variables (Tab. 3) (Cruz-Cárdenas et al., 2014) were selected for further analysis.

\section{Generation of the biotic variable}

Seven records of field observations of the presence of Apis mellifera in the study region were documented and analyzed in Maxent 3.3.3k (Phillips \& Dudick, 2008) to elaborate its ENM, and the main components generated in the previous point were used as environmental variables. In the modeling, the parameters established by default for Maxent were followed, except the commands "Extrapolate" and "Do clampling" were deactivated which are recommended only when making niche transfer models (Owens et al., 2013). The final map was exported as a logistic model without any clipping and used as the biotic variable to be used in the modeling of the species of Asteraceae (Fig. 2).

\section{Niche modeling and statistical validation of plant species}

To reduce collection bias and avoid spatial autocorrelation among records (Soberón et al., 2000), a pattern analysis was performed with each species as proposed by Cruz-Cárdenas et al. (2014). Of the thirty total species, this procedure was only executed for the ten species that had the ten or more required records. The set of uncorrelated presence data was then used to generate the model, one part for training and the other part to validate the model (testing). To construct the niche models of the thirty selected species, the parameters established by default in Maxent 3.3.3k (Phillips \& Dudick, 2008) were used, except for the deactivated "Extrapolate" and "Do clamping" options. The logistic models, were transformed to a boolean layer (presence-absence) using a species-specific cut-off threshold through the minimization of the number of omission errors using Maxent's Threshold table (Anderson et al., 2003; Phillips et al., 2006; Phillips \& Dudik, 2008).

The statistical validation of the models consisted 
Table 2.

Abiotic (environmental) variables used to construct the ecological niche models

\begin{tabular}{c} 
Climatic variables \\
BIO1= Annual Mean Temperature \\
BI012= Annual Precipitation \\
BI015= Precipitation Seasonality (Coefficient of Variation) \\
BIO3= Isothermality (BIO2/BIO7) (* 100) \\
BI04= Temperature Seasonality (standard deviation *100) \\
Seasonality climatic variables \\
PPH= Precipitation of the humid months \\
PPS= Precipitation of the dry months \\
TH= Mean temperature of humid months \\
TS= Temperature of the dry months \\
ETTRA= Real annual evapotranspiration \\
\hline ETRAS= Real evapotranspiration of the dry months (november to abril) \\
ETRAH= Real evapotranspiration of the humid months (may to october) \\
Soil properties \\
CE= Electric conductivity \\
MO= Organic material \\
pH= Hydrogen potential \\
Topographic attributes \\
ORIENT= Aspect \\
ALT= Elevation \\
PEND= Slope
\end{tabular}

Table 3.

Results of principal components analysis based on the twenty environmental variables

\begin{tabular}{cccc}
\hline Component & Standard deviation & Proportion of variance & $\begin{array}{c}\text { Cumulative } \\
\text { Proportion }\end{array}$ \\
\hline 1 & 3.35348 & 0.56229 & 0.56229 \\
2 & 1.42728 & 0.10186 & 0.66415 \\
3 & 1.29146 & 0.08339 & 0.74754 \\
4 & 1.09974 & 0.06047 & 0.80801 \\
5 & 1.00487 & 0.05049 & 0.8585 \\
6 & 0.95576 & 0.4567 & 0.90417 \\
7 & 0.71744 & 0.02574 & 0.94825 \\
\hline
\end{tabular}




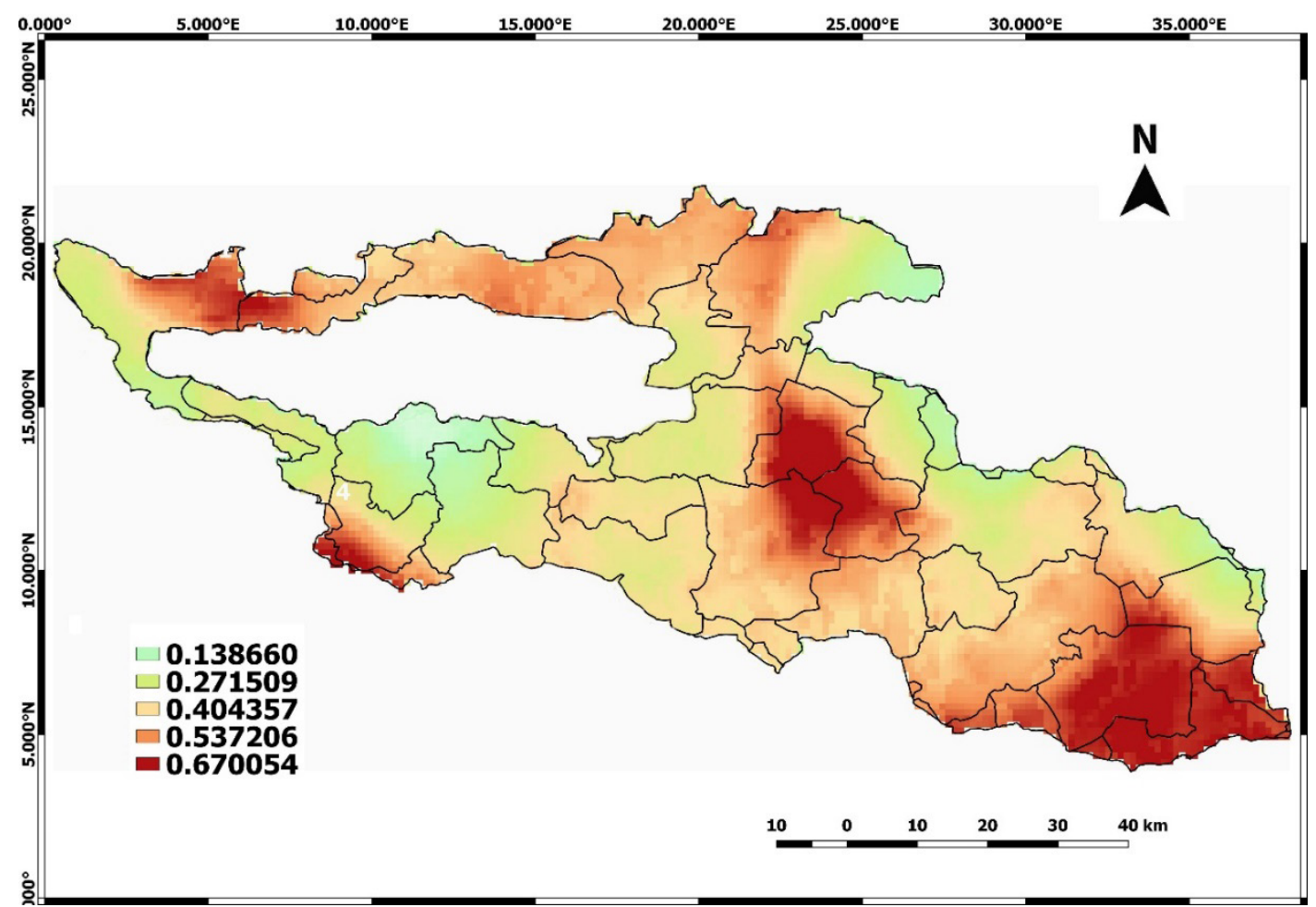

Fig. 2. Ecological niche modeling of Apis mellifera.

in three tests. First, we used the Maxent-calculated AUC value (Phillips et al., 2006) (Tab. 1). Second, the partial-ROC of each model was calculated (Peterson et al., 2008) with the use of the Partial-ROC program (Narayani, 2008) following the established parameters of $50 \%$ of the validation points resampled in 1000 replicas for bootstrap under an error of omission of less than $5 \%$ (Tab. 1), and finally a binomial test (Anderson \& González, 2011; Cruz-Cárdenas et al., 2014a), which evaluates whether a particular model is better than a randomly generated model $(p<0.5)$. The binomial test only was done for those species with ten or more records (Tab. 4).

Table 4.

Binomial test for the ten Asteraceae species with enough records to carry out the test

\begin{tabular}{|c|c|c|c|}
\hline Species & $\begin{array}{c}\text { Total records/ } \\
\text { Records predicted by } \\
\text { model }\end{array}$ & $\begin{array}{l}{ }^{*} \text { Binomial test } \\
\text { (probability of success) }\end{array}$ & $P$ value $(p \leq 0.05)$ \\
\hline 1.- Ageratum corymbosum & $5 / 5$ & 1 & 0.03125 \\
\hline 2.- Aldama dentata & $5 / 5$ & 1 & 0.03125 \\
\hline 3.- Ambrosia peruviana & $2 / 2$ & 1 & 0.25 \\
\hline 4.- Barkleyanthus salicifolius & $13 / 13$ & 0.84 & 0.01123 \\
\hline 5.- Bidens aequisquama var. aequisquama & $5 / 5$ & 1 & 0.03125 \\
\hline 6.- Dahlia coccinea & $6 / 4$ & 0.66 & 0.3437 \\
\hline 7.- Melampodium divaricatum & $21 / 19$ & 0.90 & 0.0001106 \\
\hline 8.- Melampodium perfoliatum & $3 / 3$ & 1 & 0.125 \\
\hline 9.- Tagetes erecta & $4 / 4$ & 1 & 0.0625 \\
\hline 10.- Verbesina sphaerocephala & $6 / 5$ & 0.83 & 0.1094 \\
\hline
\end{tabular}

* Null hypothesis = the probability of success is less than 0.5; Alternative hypothesis = probability of success is greater 0.5 . Probability value to reject the null hypothesis, $p \leq 0.05$. 


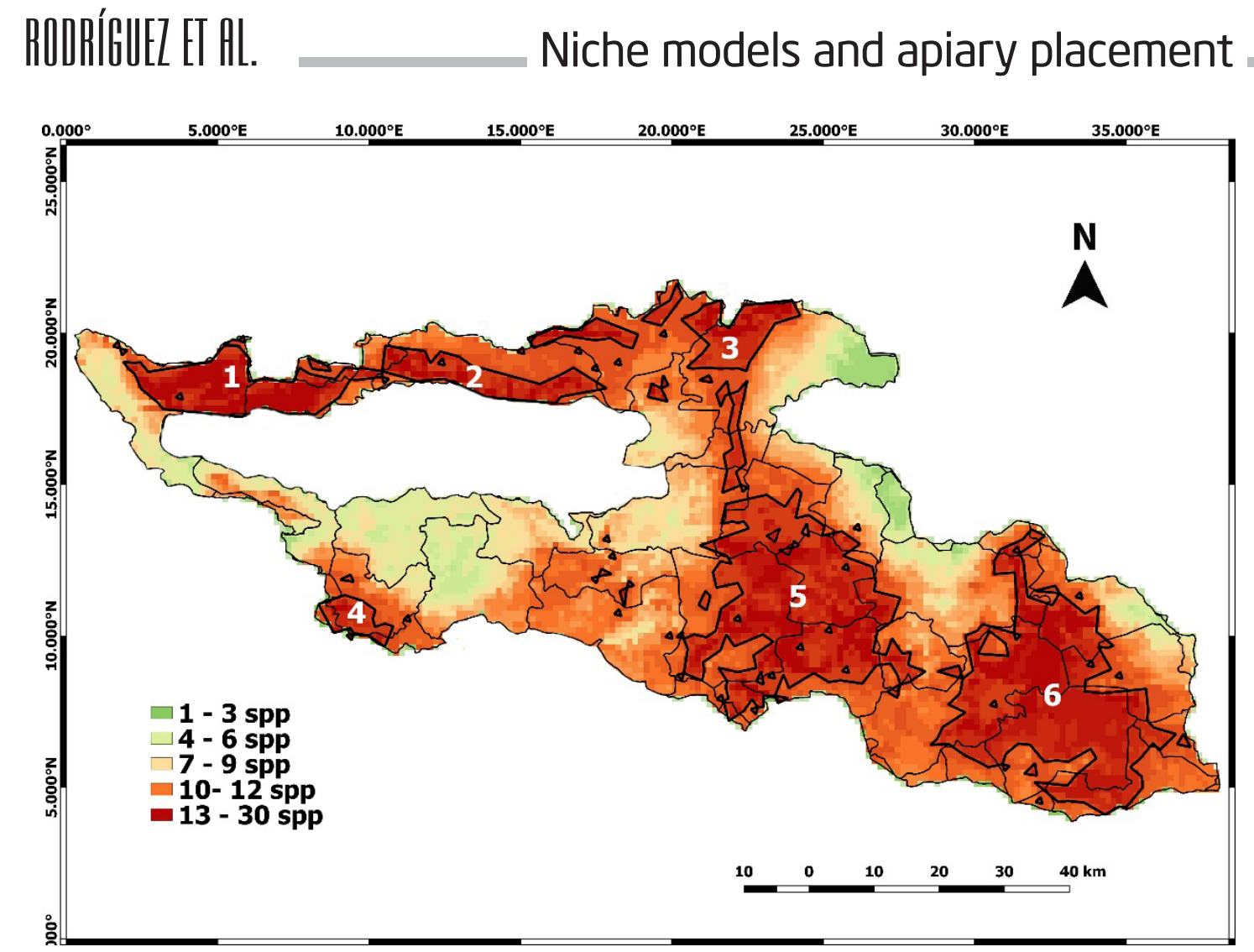

Fig. 3. Map of potential richness of Asteraceae species of beekeeping importance for the study area and environmentally suitable sites to situate apiaries.

\section{Field validation of the ENM}

To validate the ENM of the selected species in the field, first the flowering season (phenology) of the species was considered and second the visits to the majority of the municipalities according to the information provided by the ENM and the richness map obtained. The locations used to generate the model were avoided whenever possible. We made sixteen trips to the field from July to December 2017 and January to March 2018.

Determination of the ideal sites for the establishment of apiaries

Each of the models was taken in its logistic format without cutoff thresholds, including all the probability values, and a sum of all them was generated (Cianfrani et al., 2010). To choose the number of classes and intervals in the resulting map, we used the mean of the values of species richness, provided by the probability values and multiplied by the number of models (Law et al., 2009). As a result, a map of potential richness of Asteraceae species of beekeeping importance was obtained for the study area (Fig. 3), and the uppermost two classes were taken to determine the environmentally suitable sites to situate apiaries.

\section{Software used}

For the spatial analysis we used the raster and SCP plugins (Structured Conservation Planning) from the QGIS program (QGIS Development Team, 2018). For statistical analyses, we used the R statistical software gstat and sp packages (R Core Team, 2017).

\section{RESULTS}

Almost 6,000 vascular plant species are recorded in the state of Michoacán (Villaseñor, 2016), including Asteraceae 837 species (Villaseñor, 2016). A floristic inventory of the bee flora of the state records Asteraceae as the most important family, recording 43 out of 837 species. However, literature review of bee floras for other areas of Mexico revealed nineteen additional species, totaling sixty-two species of beekeeping importance that occur in the study area.

The consulted databases provided at least five records to construct ENM for thirty species 
Table 5. Loading values of the twenty environmental variables from the principal component analysis. The five variables selected for each component due to their high loading value are indicated in bold

\begin{tabular}{cccccccc}
\hline & Comp.1 & Comp.2 & Comp.3 & Comp.4 & Comp.5 & Comp.6 & Comp.7 \\
\hline ALT & $\mathbf{0 . 2 6 2}$ & 0.173 & & & & & \\
BI01 & 0.226 & $\mathbf{0 . 4 1 8}$ & 0.120 & 0.135 & & & \\
BI012 & 0.233 & $\mathbf{0 . 3 1 4}$ & 0.142 & $\mathbf{0 . 2 8 7}$ & & & \\
BI015 & 0.226 & $\mathbf{0 . 4 1 8}$ & 0.120 & 0.135 & & & \\
BI03 & 0.224 & $\mathbf{0 . 3 6 9}$ & & 0.231 & 0.128 & 0.118 & \\
BI04 & & 0.219 & 0.148 & $\mathbf{0 . 3 1 0}$ & 0.406 & $\mathbf{0 . 7 1 9}$ & \\
CE & & & $\mathbf{0 . 4 8 5}$ & $\mathbf{0 . 4 1 8}$ & 0.410 & $\mathbf{0 . 1 9 2}$ & \\
ETRA_AN & $\mathbf{0 . 2 8 0}$ & 0.167 & & & & & \\
ETRAH & $\mathbf{0 . 2 7 8}$ & 0.160 & & & & & \\
ETRAS & 0.255 & $\mathbf{0 . 2 2 0}$ & 0.146 & 0.109 & & 0.101 & \\
MO & 0.238 & 0.125 & & 0.106 & & & $\mathbf{0 . 1 3 0}$ \\
NDVIHUM & 0.139 & 0.184 & $\mathbf{0 . 4 5 1}$ & $\mathbf{0 . 4 4 7}$ & 0.146 & & \\
NDVISEC & 0.142 & 0.168 & $\mathbf{0 . 4 9 1}$ & $\mathbf{0 . 3 9 7}$ & 0.112 & & $\mathbf{0} .187$ \\
ORIENT & & 0.171 & & 0.191 & $\mathbf{0 . 7 1 8}$ & $\mathbf{0 . 5 5 6}$ & $\mathbf{0 . 2 8 9}$ \\
PEND & 0.192 & & 0.198 & 0.116 & $\mathbf{0 . 2 2 8}$ & $\mathbf{0 . 1 8 6}$ & $\mathbf{0 . 8 9 8}$ \\
PH & $\mathbf{0 . 2 7 2}$ & 0.144 & 0.173 & 0.137 & & & \\
PPH & 0.278 & 0.160 & & & & & \\
PPS & 0.255 & $\mathbf{0 . 2 2 0}$ & 0.146 & 0.109 & & 0.101 & \\
TH & 0.253 & & $\mathbf{0 . 2 4 5}$ & 0.267 & & $\mathbf{0 . 1 8 2}$ & \\
TS & $\mathbf{0 . 2 6 0}$ & 0.157 & $\mathbf{0 . 2 2 2}$ & 0.122 & & & \\
\hline
\end{tabular}

(Tab. 1). Among the most common species found in the area, Aldama dentata La Llave, Baccharis salicifolia (Ruiz \& Pav.) Pers., Melampodium divaricatum (Rich.) DC., and Verbesina sphaerocephala A. Gray are widely recognized for their frequent bee visits. The other thirty-two species documented in the bee flora of the region did not have enough records for ENM models, but their occurrence information was used to improve the richness map (Appendix 2). According to the load values of the principal components, fourteen out of twenty environmental variables were important for the species modeling (Tab. 5) and were used to generate the ENM. The statistical validation of the models with the AUC-Maxent and AUC tests of the partial ROC categorize the models as bad if they have a value lower than 0.60, regular with a value between 0.60 and 0.70 and good with values between 0.80 and 1 . Based on this classification, the AUC-Maxent test considered all models from regular to good with values ranging from 0.70 the lowest to 0.95 the highest (Tab. 1). For the partial ROC test, all models were considered good with values from 0.98 to 1 . Among the species in which the binomial test was conducted, all models had values of 1 or close to 1 (Tab. 4) and were better than a randomly generated model.

In the field, twenty-three of the thirty modeled species were found. Of those, five were found only one additional time, while the other eighteen species yielded between two and twelve new records within the study area during our fieldwork (Tab. 1).

The map summing the thirty ENM revealed 
richness values ranging from one to thirty species. Using the uppermost classes of potential richness (13-30 species), six important areas with species of beekeeping importance were determined (Fig. 3). These six areas represent the most environmentally suitable sites for the placement of apiaries, which were located in twenty-five municipalities of the study area (Appendix 1).

\section{DISCUSSION}

Austin (2002) mentioned that environmental variables influence directly or indirectly ENM. Such direct variables as temperature and precipitation variables affect the physiology of organisms and can be a determinant for their survival, and indirect variables as topographic variables, latitude or altitude do not drastically impact the physiology of organisms but affect their geographical distribution. Considering Austin's assumptions and the results obtained in the PCA (Tab. 5) for twenty of the studied species, at least three important variables, annual evapotranspiration (ETRA-A), evapotranspiration of the wet months (ETRA-H) and pH may directly affect their occurrence, and altitude (ALT) may influence them indirectly (Tab. 5). For the ten remaining species, annual precipitation (BI012), temperature seasonality (BI04), temperature of the humid months (TH), temperature of the dry months (TS), standardized vegetation indexes (NDVIH, NDVIS), electrical conductivity (CE) and organic matter (OM) are variables possibly influencing occurrence directly, while orientation (ORIENT) and slope (PEND) indirectly (Tab. 5).

The ENM of the modeled species echoed the environmental suitability of each species within the study area. In all the models, the suitability was observed to be geographically broader than the spatial distribution of known occurrences (Appendix 3). The maximum entropy algorithm uses each training records to maximize the occurrence of the object (species), seeking a uniform distribution throughout the study area (Phillips et al., 2006; Phillips \& Dudik, 2008; Elith \& Leathwick, 2009; Fithian \& Hastie, 2012). In addition, the models were made with the default configuration; when such configurations as regularization parameters $\beta$ are changed in Maxent, non-overadjusted and more restricted models can be obtained (Anderson \& González, 2011). For this reason, in many works related to niche modeling, statistical parameters are used to evaluate the models, e.g. Maxent's AUC, partial ROC and binomial test (Peterson et al., 2008; Anderson \& González, 2011; Cruz-Cárdenas et al., 2014; Martínez-Méndez et al., 2016). Whether the models are made with the default configuration or modified parameters of the configuration, the purpose of the evaluation is to reflect the statistical robustness of the models. For the thirty MNE elaborated, the statistical parameters indicated they were statistically robust models.

The values of AUC-Maxent partial ROC (Peterson \& Soberón, 2008; Baldwin, 2008; Peterson et al., 2011; Martínez-Méndez et al., 2016), indicate the models are regular to good, with a minimum values of 0.70 and maximum of 1 (Tab. 1). Similarly, the binomial test showed values of success of 1 or close to 1 , and the models are better than a randomly generated model (Tab. 4). The statistical robustness of the models resulted in an $80 \%$ ENM success rate, considering that twenty-three of the thirty species of beekeeping importance were actually found during field trips. Peterson et al. (2011) mentioned that ENM can be used to find new populations of species in places that had not been previously explored.

Seven species were not observed during field work: Ageratina mairetiana var. mairetiana, Astranthium orthopodum, Bidens aurea, Guardiola mexicana var. mexicana, Pittocaulon velatum var. velatum, Pluchea carolinensis, and Viguiera dentata. Several arguments can be proposed to explain their lack of new populations, and perhaps the most important is habitat transformation. An important portion of the study area is now occupied by agricultural fields, where such agricultural techniques as herbicides or quilts (weed cloth) are commonly used to eliminate weeds, may influence their absence in the landscape. Cousens and Mortimer (1995) argue these agricultural practices modify popu- 
lations' densities and seedbank composition and result in changes in floristic composition.

The six environmentally suitable zones concentrating the largest richness of Asteraceae modeled, show a high coincidence with the ENM of Apis mellifera (Fig. 2 and 3). These areas therefore combine the two key conditions for apiary placement: high probability of occurrence of bees and a broad spectrum of bee-important plant species. Data on honey production in the study region (SIAP, 2015) record the highest honey production in the municipalities of Jamay in the state of Jalisco and Zamora in the state of Michoacán, about 861 and 81 tons per year, respectively. The ideal apiary areas identified as zones 5 and 3 in our maps are located in these municipalities. In total the six high-richness sites represent an area of $2,488 \mathrm{~km}^{2}, 34 \%$ of the total $7,376 \mathrm{~km}^{2}$ study area. Thus, the search for ideal sites for apiaries settlement can be significantly narrowed down through the use of ENMs. The thirty species with ENM out of sixty-two occurring in the study area plus fourteen out of twenty environmental variables considered important in model generation, allowed us to identify six important areas where conditions would favor beekeeping activities. These areas were confirmed as important once fieldwork validated the occurrence of the twenty-three out of thirty bee-important plant species in localities where they had not been previously searched for. It is well known that the larger the number of bee important species in a region, the better the honey production. The healthy condition of the honeycomb depends on the quality of the pollen collected (floral resources). Therefore, if a large number of species that bees feed on are present around the hive, the survival of the colony is more likely and the quality of honey produced will increase.

The Asteraceae species analyzed in this study are among the most important and frequently cited in beekeeping studies. Thus, the areas identified as important in this paper will play an important role in the improvement of local honey production. We hope that such governmental institutions as SAGARPA and SEMARNAT in Mexico will apply our information in the near future to find the most environmentally suitable sites and assist beekeepers in the search for apiary locations.

\section{ACKNOWLEDGMENTS}

JCR thanks the Mexican National Council of Science and Technology (CONACYT) for the graduate student scholarship (612801). Enrique Ortiz assisted with technical support in database management and with comments to the manuscript. Lynna Kiere reviewed the English version.

\section{REFERENCES}

Acosta-Castellanos, S., Quiroz-García, L. ArreguínSánchez, M. de la L. \& Fernández-Nava, R. (2011). Análisis polínico de tres muestras de miel de Zacatecas, México. Polibotánica, 32, 179-191.

Alvarado-Cárdenas, L. O., Villaseñor, J. L., López-Mata, L., Cadena, J. \& Ortiz, E. (2017). Systematics, distribution and conservation of Cascabela (Apocynaceae: Rauvolfioideae: Plumerieae) in Mexico. Plant Systematics and Evolution, 303(3), 337-369. https:// doi.org/10.1007/s00606-016-1375-6

Anderson, R.P., \& González, I. Jr. (2011). Speciesspecific tuning increases robustness to sampling bias in models of species distributions: An implementation with Maxent. Ecological Modelling, 222(15), 2796-2811. https://doi.org/10.1016/j. ecolmodel.2011.04.011

Anderson, R. P., Lew, D., \& Peterson, A. T. (2003). Evaluating predictive models of species distributions: criteria for selecting optimal models. Ecological Modelling, 162(3), 211-232. https://doi.org/10.1016/ s0304-3800(02)00349-6

Austin, M. P. (2002). Spatial prediction of species distribution: an interface between ecological theory and statistical modelling. Ecological Mode/ling, 157, 101-118, https://doi.org/10.1016/S03043800(02)00205-3

Baldwin, R. A. (2008). Den-Site characteristics of 
black bears in rocky Mountain National Park, Colorado. Journal Of Wildlife Management, 7ð(8), 17171724. https://doi.org/10.2193/2007-393

Barrios, C., Morales, Y., Cugnata, N., Piano, F. D., Fuselli, S., Maggi, M. \& Principal, J. (2012). La apicultura como estrategia de gestión ambiental en la cuenca de embalse Guaremal, municipio Peña, estado Yaracuy, Venezuela. Zootecnica Trop, 30(2), 269-284.

Bello-González, M. A. (2007). Plantas melíferas silvestres de la Sierra Purépecha, Michoacán, México. Ciencia Forestal en México, 32(102), 103-126.

Bradbear, N. (2005). La apicultura y los medios de vida sostenibles. Folleto de la Food and Agriculture Organization (FAO) sobre diversificación, Roma, http://www.fao.org/docrep/008/y5110s/y5110s00. htm

Castellanos-Potenciano, B. P." Ramírez-Arriaga, E., \& Zaldivar-Cruz, J. M. (2012). Análisis del contenido polínico de mieles producidas por Apis mellifera L. (Hymenoptera: Apidae) en el estado de Tabasco, México. Acta Zoológica Mexicana, 28(1), 13-36.

Cianfrani, C., Le Lay, G., Hirzel, A. H. \& Loy, A. (2010). Do habitat suitability models reliably predict the recovery areas of threatened species. Journal of Applied Ecology, 4オ2), 421-430. https://doi.org/10.1111/ j.1365-2664.2010.01781.x

Cordova-Cordova, c. I. (2009). Determinación geográfica y botánica de miel de abeja (Apis mellifera L.) del estado de Tabasco, México. Tesis Maestría. Colegio de Posgraduados. Tabasco, México. 147 pp.

Cousens, R. \& M. Mortimer. (1995). Dynamics of weed populations. (pp. 14-19) Cambridge University Press.

Cruz-Cárdenas, G., López-Mata, L., Villaseñor, J. L. \& Ortiz, E. (2014). Potencial species distribution modeling and the use of principal component analysis as predictor variables. Revista Mexicana de Biodiversidad, 85(1), 189-199. https://doi.org/10.7550/ rmb.36723

Cruz-Cárdenas, G., Villaseñor, J. L., López-Mata, L.,
Martínez-Meyer, E. \& Ortiz, E. (2014a). Selección de predictores ambientales para el modelado de la distribución de especies en Maxent. Revista Chapingo Serie Ciencias Forestales y del Ambiente, 202), 188-201.

Cruz-Cárdenas, G., López-Mata, L., Ortiz-Solorio, C. A., Villaseñor, J. L., Ortiz, E., Silva, J. T. \& Estrada-Godoy, F. (2014b). Interpolación of Mexican soil properties at a scale of 1:1,000,000. Geoderma, 213, 29-35. https:// doi.org/10.1016/j.geoderma.2013.07.014

Cruz-Cárdenas, G., López-Mata, L., Silva, J. T., BernalSantana, N., Estrada-Godoy, F. \& López-Sandoval, J. A. (2016). Potential distrribution model of Pinaceae species under climate change scenarios in Michoacán. Revista de Chapingo Serie Ciencias Forestales y del Ambiente, 22(2), 135-148. http://dx.doi. org/10.5154/r.rchscfa.2015.06.027

de la Mora-González, C. H. (1988). Flora de Utilidad Apícola en Jalisco. Tesis Licenciatura. Universidad de Guadalajara, Facultad de Agrícultura, 87 pp.

DIVA-GIS. (2016). versión 7.5. http://www.diva-gis. org/docs/DIVA-GIS_manu

Elith, J., Graham, C., Anderson, R., Dudik, M., Ferrier, S., Guisan, A., ... Zimmermann. N. (2006). Novel methods improve prediction of species distributions from ocurrence data. Ecography 29,129-151.

Elith, J., \& Leathwick, J. (2009). Species distribution models: ecological explanation and predictions across space and time. Annual Review of Ecology, Evolution and Systematics, 40, 677-697.

Estrada, A. S., Ortiz, E., Villaseñor, J. L. \& EspinosaGarcía, F. J. (2016). The distribution of cultivated species of Porophyllum (Asteraceae) and their wild relatives under climate change. Systematics and Biodiversity, 14(6), 572-582. https://doi.org/10.1080/1 4772000.2016 .1205678

FAO. (2014). Principios y avances sobre polinización como servicio ambiental para la agricultura sostenible en países de Latinoamérica y El Caribe. Organización de las Naciones Unidas para la Alimentación 


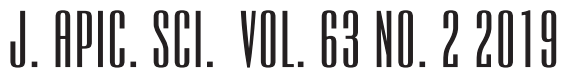

y la Agricultura. Santiago, Chile.

FAO. (2017). Organización de las Naciones Unidad para la Alimentación y la Agricultura. Retrieved January 22, 2019, from http://www.fao.org/faostat/ es/\#data/FBS

Feria-Arroyo, T. P., Sánchéz-Rojas, G., Ortiz-Pulido, R., Bravo-Cadena, J., Calixto-Pérez, E., Dale, J. M., Duberstein, J. N., Illoldi-Rangel, P., Lara, C. \& ValenciaHerverth, J. (2013). Estudio del cambio climático y su efecto en las aves en México: enfoques actuales y perspectivas futuras. Huitzil, 14, 47-55.

Fithian, W., \& Hastie, T. (2012). Statistical models for presence-only data: finite-sample equivalence and addressing. Stanford University.

Galarza-Mendoza, J. L., Reyes-Carrillo, J. L., Muñoz-Soto, R. \& Moreno-Reséndez, A. (2012). Diagnóstico del potencial apiflorístico a través del polen almacenado en la colmena en dos municipios de la Comarca Lagunera. Memorias del $19^{\circ}$ Congreso Internacional de Actualización Apícola, Oaxaca, México. 50-55 p.

Gallardo, A. (2006). Geoestadística. Ecosistemas, 3, 49-59.

Gil, G.E., \& Lobo, J. M. (2012). El uso de modelos predictivos de distribución para el diseño de muestreos de especies poco conocidas. Mastozoología Neotropical, 19, 47-62.

González-Sandoval, R., Catalán-Heverástico, C., Domínguez-Márquez, V. M., Luna-León, C., Hernández-Castro, E., Damián-Nava, A., Cruz-Lagunas, B., Palemón, F.A. (2016). Análisis palinológico de los recursos florales utilizados por Apis mellifera L. (Hymenoptera:Apidae) en cuatro municipios del estado de Guerrero, México. Tropical and Subtropical Agroecosystems, 19, 19-28.

Goovaerts, P. (1999). Geostatistics in soil science: state-of-the-art and perspectives. Geoderma, 89(1-2), 1-45. https://doi.org/10.1016/S00167061(98)00078-0

Hengl, T. (2006). Finding the right pixel size. Com- puters y Geosciences, 32(9), 1283-1298. https://doi. org/10.1016/j.cageo.2005.11.008

INEGI. (2006). Conjunto de datos de perfiles de suelos, escala 1:250000 serie II (Continuo Nacional). Instituto Nacional de Estadística y Geografía. http:// www.inegi.org.mx/geo/contenidos/recnat/edafologia/vectorial_serieili.aspx

INEGI. (2017). Modelo Continuo de Elevaciones Mexicano 3.0 (CEM). Instituto Nacional de Estadística y Geografía. Aguascalientes, Aguascalientes.

Jegede, A. (2019). Top 10 largest honey producing countries in the world. Food \& Beverage. https:// www.trendrr.net/6124/top-10-largest-honey-producing-countries-world-famous-best/\#7_Mexico. Last search January 22, 2019.

Lane, A., \& Jarvis, A. (2007). Changes in climate will modify the geography of crop suitability: Agricultural biodiversity can help with adaptation. Journal of Semi-arid Tropical Agricultural Research, 4(1), 1-12. http://citeseerx.ist.psu.edu/viewdoc/download?doi= 10.1.1.500.8632\&гер=гер1\&type=pdf

Law, M. C., Balasundram, S. K., Husni, M. H., Ahmed, O. H. \& Harum, M. H. (2009). Spatial variability of soil organic carbón in oil palm. International Journal of Soil Science, 4, 93-103.

Manrique, E. G. (1999). Índice de vegetación aplicación del NDVI. TELEDETECCIÓN. Avances y Aplicaciones. VIII Congreso Nacional de Teledetección. Albacete, España 217-219 pp.

Martínez-Méndez, N., Aguirre-Planter, E., Eguiarte, L..E., \& Jaramillo-Correa, J. P. (2016). Modelado de Nicho ecológico de las especies del género Abies(Pinaceae) en México: algunas implicaciones taxonómicas y para la conservación. Botanical Sciences, 94(1), 5-24. http://dx.doi.org/10.17129/botsci.508

Montoy-Koh, L. A. (2010). Estudio apibotánico para un mejor aprovechamiento de los recursos natuarles en la región de las montañas, Veracruz. Tesis Licenciatura. Secretaria de Educación Pública Subsecretaría de Educación Superior, Dirección General de Edu- 


\section{Aondífulez Et H.}

Niche models and apiary placement

cación Superior Tecnológica, Instituto Tecnológico de China.

Narayani, B. (2008). Tool for Partial-ROC (Biodiversity Institute, Lawrence, KS), ver 1.0.

Nates-Parra, G., Montoya, P.M., Chamorro, F.J., Ramírez, N., Giraldo, C., Obregon, D. (2013). Origen geográfico y botánico de mieles de Apis mellifera (Apidae) en cuatro departamentos de Colombia. Acta Biológica Colombiana, 18(3), 427-437.

Owens, H. L., Campbell, L. P., Dornak, L. L., Saupe, E. E., Barve, N., Soberòn, J. \& Peterson, A. T. (2013). Contraints on interpretation of ecological niche models by limited enviromental ranges on calibration areas. Ecological Modelling, 263, 10-18. https://doi. org/10.1016/j.ecolmodel.2013.04.011

Palma-Ordaz, S., \& Delgadillo-Rodríguez, J. (2014). Distribución potencial de ocho especies exóticas de carácter invasor en el estado de Baja California, México. Botanical Sciences, 92(4), 587-597. http:// dx.doi.org/10.17129/botsci.135

Peterson, A. T., Sanchez-Cordero, V., Martínez-Meyer, E., Navarro-Sigüenza, A. G. (2006). Tracking population extirpations via melding ecological niche modeling with land-cover information. Ecological Modelling, 195(3-4), 229-236. https://doi.org/10.1016/j. ecolmodel.2005.11.020

Peterson, A. T., Papes, M., \& Soberón, J. (2008). Rethinking receiver operating characteristic analysis applications in ecological niche modeling. Ecological Modelling, 273(1), 63-72. https://doi.org/10.1016/j. ecolmodel.2007.11.008

Peterson, A. T., Soberón, J., Person, R. G., Anderson, R. P., Martínez-Meyer, E., Nakamura, M. \& Araujo, M. B. (2011). Ecologica/ Niches and Geographic Distributions. Princeton University Press.

Phillips, S. J., Anderson, R.P., \& Schapire, R. (2006). Maximum entropy modeling of geographic distributions. Ecological Modelling, 190, 231-259. https://doi. org/10.1016/j.ecolmodel.2005.03.026
Phillips, S. J.. \& Dudik, M. (2008). Modeling of species distributions with Maxent: new extensions and a comprehensive evaluation. Ecography, 37(2), 161-175. https://doi.org/10.1111/j.09067590.2008.5203.x

Piedras-Gutiérrez, B., \& Quiroz-García, D. L. (2007). Estudio Melisopalinologico de dos mieles de la porción Sur del Valle de México. Polibotánica, 23, 57-75.

Polce, Ch., Termanse, M., Aguirre-Gutiérrez, J., Boatman, N. D., Budge, G. E., Crowe, A., ... Biesmeijer, J. C. (2013). Species distribution models for Crop Pollination: A modelling framework applied to Great Britain. PLOS One, 8(10), 1-12. https://doi.org/10.1371/journal.pone.0076308

Porter-Bolland, L., Medina-Abreu, M. E., Monroy Koh, J. A., Montoy-Koh, P., Martin-Ek, G., May-Pacheco, G. (2009). Flora melifera de la Montaña, Campeche: su importancia para la apícultura y para la vida diaria. Comisión Nacional para el Conocimiento y Uso de la Biodiversidad e Instituto de Ecología, A. C., Xalapa, Ver., México.

van Proosdij, A. S. J., Sosef, M. S., Wieringa, J. J., \& Raes, N. (2016). Minimum required number of specimen records to develop accurate species distribution models. Ecography, 39(6), 542-552. https://doi. org/10.1111/ecog.01509

QGIS Development Team (2018). QGIS Geographic Information System. Open Source Geospatial Foundation Project. https://qgis.org.

Quiroz-García, D. L., \& Arreguín-Sánchez, M. de la L, (2008). Determinación palinológica de los recursos florales utilizados por Apis mellifera L. (Hymenoptera: Apidae) en el estado de Morelos, México. Polibotánica, 26, 159-173.

R Core Team (2017). R: A language and environment for statistical computing. R Foundation for Statistical Computing, Vienna, Austria. URL https://www.Rproject.org/.

Ramírez-Arriaga, E., Navarro-Calvo, L. A., \& Díaz-Carbajal, E. (2011). Botanical characterization of Mexican 


\section{J. APIC. SLI. VOL. 63 ND. 2 2019}

honeys from a subtropical región (Oaxaca) based on pollen analysis. Grana, 5011), 40-54. https://doi.org/1 0.1080/00173134.2010.537767

Ramírez-Arriaga, E., Martínez-Bernal, A., \& RamírezMaldonado, N.. (2016). Análisis palinológico de mieles y cargas de polen de Apis mellifera (Apidae) de la Región Centro y Norte del estado de Guerrero, México. Botanica/Sciences, 94(1), 141-156. http://dx.doi. org/10.17129/botsci.217

SAGARPA. (2011). Manual básico de Apicultura. Secretaría de Agricultura, Ganadería, Desarrollo Rural, Pesca y Alimentación. México, D. F.

SAGARPA. (2011a). Manual de polinización Apícola. Secretaría de Agricultura, Ganadería, Desarrollo Rural, Pesca y Alimentación. México, D. F.

SAGARPA. (2015). Manual de buenas prácticas pecuarias en la producción de miel. Secretaría de Agricultura, Ganadería, Desarrollo Rural, Pesca y Alimentación. México, D. F.

SAGARPA. (2015a). Secretaria de Agricultura, Ganadería, Desarrollo Rural, Pesca y Alimentación. http:// www.gob.mx/sagarpa. Last search 12. V. 2016.

Sánchez-Cordero, V., Illoldi-Rangel, P., Linaje, M. A., Sarkar, S. \& Peterson, A. T. (2005). Deforestation and extant distributions of Mexican endemic mammals. Biological Conservation, 126(4), 465-473. https:// doi.org/10.1016/j.biocon.2005.06.022

Santana-Michel, F. J., Cervantes-Aceves, N., \& Jiménez-Reyes, N. (1998). Flora melífera del estado de Colima, México. IBUG, Boletín del Instituto de Botánica, 6, 251-277.

Servicio de Información Agroalimentaria y Pesquera. SIAP. (2015). http://infosiap.siap.gob.mx/gobmx/datosAbiertos.php. Last search August 23, 2016.

Soberón, J. (2007). Grinnellian and Eltonian niches and geographic distributions of species. Ecology Letters, 10(12), 1115-1123. https://doi.org/10.1111/ j.1461-0248.2007.01107.x
Soberón, J. (2010). Niche and area of distribution modeling: a population ecology perspective. Ecography, 33(1), 159-167. https://doi.org/10.1111/j.16000587.2009.06074.x

Soberón, J. M., Llorente, J. B., \& Oñate, L. (2000). The use of specimen-label databases for conservation purposes: an example using Mexican Papilionid and Pierid butterflies. Biodiversity and Conservation, 9(10), 1441-1466. https://doi. org/10.1023/A:1008987010383

Soberón, J., \& Peterson, A. T. (2005). Interpretation of models of fundamental ecological niches and species distributional areas. Biodiversity Informatics, 2, 1-10. https://doi.org/10.17161/bi.v2i0.4

Turc, L. (1954). Le bilan d'eau des sols: relations entre les precipitation l'évaporation et l'écoulemen. Annales Agronomiques, 5, 491-596.

Verde, M. M. (2014). Apiculture and food safety. Cuban Journal of Apicultural Science, 48, 25-31.

Villanueva-Gutierrez, R, Moguel-Ordónez, Y.B., Echazarreta-González, C. M., \& Aranda-López, G. (2009). Monofloral honeys in the Yucatán Peninsula, Mexico. Grana, 48(3), 214-223. https://doi. org/10.1080/00173130902929203

Villanueva-Gutierrez, R, Moguel-Ordónez, Y.B., Echazarreta-González, C. M., \& Aranda-López, G. (2009). Monofloral honeys in the Yucatán Peninsula, Mexico. Grana, 48(3), 214-223. https://doi. org/10.1080/00173130902929203

Villegas-Durán, G., Bolaños-Medina, A., MirandaSánchez, J. A., Luis Quintana-Rocha, I., GuzmánQuintana, E. O. \& Zavala-Ruiz, J. J. M. (1999). Flora nectarífera y polinífera en el estado de Michoacán. Secretaria de Agricultura, Ganadería y Desarrollo Rural. México, D. F.

Villegas-Durán, G., Bolaños-Medina, A., MirandaSánchez, J. A., García-Aldape, J. \& Galván-García, O. M. (2000). Flora nectarífera y polinífera en el estado de Tamaulipas. Secretaria de Agricultura, Ganadería y Desarrollo Rural. México, D. F. 
Villegas-Durán, G., Bolaños-Medina, A., MirandaSánchez, J. A., Sandoval-Hernández, R. \& LizamaManrique, J. M. (2003). Flora nectarífera y polinífera en el estado Veracruz. Secretaría de Agricultura, Ganadería y Desarrollo Rural. México, D. F.

Villaseñor, J. L. (2016). Checklist of the native vascular plants of Mexico. Revista Mexicana de Biodiversidad, 873), 559-902. https://doi.org/10.1016/j. rmb.2016.06.017

Villaseñor, J. L., \& Ortiz, E.. (2014). Biodiversidad de las plantas con flores (División Magnoliophyta) en México. Revista Mexicana de Biodiversidad, 85(1), 134142. https://doi.org/10.7550/rmb.31987
Villaseñor, J. L., Ortiz, E., Cadena-Rodríguez, J., \& Estrada, A. S. (2013). Patrones de riqueza florística en el estado de Jalisco: La tribu Senecioneae (Asteraceae) como estudio de caso. Ibugana, 4, 63-78. 
Appendix 1.

Municipalities of the state of Michoacán that are in the Chapala and Duero River basins. The selected area corresponds to the main zone identified as a priority агеa for apiary placement (Figure 3)

\begin{tabular}{|c|c|c|}
\hline Basin & Municipality & Selected Area \\
\hline Chapala & Acatlán de Juárez & \\
\hline Chapala & Atotonilco el Alto & \\
\hline Chapala & Ayotlán & 1 \\
\hline Chapala/Duero & Briseñas & \\
\hline Chapala & Cojumatlán de Regules & \\
\hline Chapala & Concepción de Buenos Aires & 4 \\
\hline Chapala & Cotija & \\
\hline Chapala & Chapala & \\
\hline Duero & Charapan & 6 \\
\hline Duero & Chavinda & 5 \\
\hline Duero & Cherán & 6 \\
\hline Duero & Chilchota & 6 \\
\hline Duero & Churintzio & \\
\hline Duero & Ecuandureo & \\
\hline Chapala & Ixtlahuacán de los Membrillo & 1 \\
\hline Duero & Ixtlán & \\
\hline Duero & Jacona & \\
\hline Chapala & Jamay & 3 \\
\hline Chapala & Jiquilpan & \\
\hline Chapala & Jocotepec & 1 \\
\hline Chapala & La Barca & 3 \\
\hline Chapala & La Manzanilla de la Paz & 4 \\
\hline Duero & Los Reyes & 6 \\
\hline Chapala & Marcos Castellanos & \\
\hline Chapala & Mazamitla & 4 \\
\hline Duero & Nahuatzen & \\
\hline Chapala & Ocotlán & 3 \\
\hline Chapala/Duero & Pajacuarán & 5 \\
\hline Duero & Рагасhо & 6 \\
\hline Duero & Penjamillo & \\
\hline Chapala & Poncitlán & 2 \\
\hline Duero & Puréрего & 6 \\
\hline Chapala & Quitupan & \\
\hline Chapala & Sahuayo & \\
\hline Chapala/Duero & Tangamandapio & 5 \\
\hline Duero & Tangancícuaro & 6 \\
\hline Duero & Tanhuato & \\
\hline
\end{tabular}


Chapala

Chapala

Chapala

Chapala

Duero

Chapala

Chapala

Chapala

Chapala

Chapala/Duero

Chapala/Duero

Duero

Duero

Chapala

Duero

Chapala
Teocuitlan de Corona

Tinguindin

Tizapán el Alto

Tlajocomulco de Zuñiga

Tlazazalca

6

Tocumbo

Tototlan

Tuxcueca

Valle de Juarez

Venustiano Carranza

Villamar

5

5

Vista Hermosa

Zacapu

6

Zacoalco de Torres

Zamora

5

Zapotlán de Rey 
Appendix 2.

Species of Asteraceae of bee importance occurring in the study area and their distribution among the Mexican states. (Cam= Campeche, Chis= Chiapas, Col= Colima, Cdmx= Ciudad de México, Dgo= Durango, Gro= Guerrero, Jal= Jalisco, Mich= Michoacán, Mor= Morelos, Oax= Oaxaca, Tab= Tabasco, Tams= Tamaulipas, Ver= Veracruz, Yuc= Yucatán)

\begin{tabular}{|c|c|c|c|c|c|c|c|c|c|c|c|c|c|c|}
\hline Species & Cam & Chis & Col & CdMx & Dgo & Gro & Jal & Mich & Mor & Oax & Tab & Tams & Ver & Yuc \\
\hline Achillea millefolium & & & & & & & & & & & & & $x$ & \\
\hline Acmella repens & & & & & & & & $\mathrm{x}$ & & & & & & \\
\hline $\begin{array}{c}\text { Ageratina mairetiana } \\
\text { var. mairetiana }\end{array}$ & & & & & & & & $\mathrm{x}$ & & & & & $\mathrm{x}$ & \\
\hline $\begin{array}{l}\text { Ageratum } \\
\text { corymbosum }\end{array}$ & & & $\mathrm{x}$ & & & & & & & & & & & \\
\hline Aldama dentata & & & & & & $x$ & & & & & $x$ & & $x$ & \\
\hline Aldama linearis & & & & & & & $x$ & & & & & & & \\
\hline Aldama pachycephala & & & & & & & $x$ & & & & & & & \\
\hline Ambrosia peruviana & & & & & & & & & & & & & $x$ & \\
\hline $\begin{array}{l}\text { Astranthium } \\
\text { orthopodum }\end{array}$ & & & & & & & & $\mathrm{x}$ & & & & & & \\
\hline $\begin{array}{l}\text { Baccharis } \\
\text { heterophylla }\end{array}$ & & & $x$ & & & & & $\mathrm{x}$ & & & & & & \\
\hline Baccharis salicifolia & & & $x$ & & $x$ & & $x$ & & & & & $x$ & & $x$ \\
\hline $\begin{array}{l}\text { Barkleyanthus } \\
\text { salicifolius }\end{array}$ & & & & & & & & $\mathrm{x}$ & & & & $\mathrm{x}$ & $\mathrm{x}$ & \\
\hline Bidens aequisquama & & & & & & & & $x$ & & & & & & \\
\hline Bidens aurea & & $x$ & & & & $x$ & & & & & & & & \\
\hline Bidens bigelovii & & & & & & & & & $x$ & & & & & \\
\hline Bidens chiapensis & & $x$ & & & & & & & & & & & & \\
\hline Bidens laevis & & & & & & & & $x$ & & & & & & \\
\hline Bidens odorata & & & & $x$ & & $x$ & & & & $x$ & & $x$ & & \\
\hline Calea ternifolia & & & $x$ & & & & & & & & & & & \\
\hline Calea urticifolia & & $x$ & $x$ & & & & $x$ & & & & & & & \\
\hline Calyptocarpus vialis & & & & & $x$ & & & & & & & & & \\
\hline Cosmos bipinnatus & & & & & & & $x$ & $x$ & & & & & & \\
\hline Cosmos sulphureus & & $x$ & $x$ & & & $x$ & $x$ & & & & & & & \\
\hline Chromolaena collina & & & $x$ & & & & & & & & & & & \\
\hline Chromolaena odorata & & & & & & & & & & & & $x$ & $x$ & \\
\hline Dahlia coccinea & & & $x$ & & & & $x$ & & & & & & & \\
\hline Dyssodia papposa & & & & & & $x$ & & & & & & & & \\
\hline Erigeron longipes & & & & & & & & $x$ & & & & & & \\
\hline Galinsoga parviflora & & & & & & & & $x$ & & & & & & \\
\hline Guardiola mexicana & & & & & & & & $x$ & & & & & & \\
\hline $\begin{array}{l}\text { Lasianthaea } \\
\text { ceanothifolia }\end{array}$ & & & $\mathrm{x}$ & & & & & & & & & & & \\
\hline Lasianthaea fruticosa & & $x$ & & & & & & & & & & & & \\
\hline
\end{tabular}


Melampodium divaricatum

Melampodium perfoliatum

Montanoa bipinnatifida

Montanoa karwinskii

Montanoa leucantha subsp. arborescens

Montanoa tomentosa subsp. xanthiifolia

Otopappus tequilanus

Parthenium hysterophorus

Pittocaulon velatum var. velatum

Pluchea carolinensis Pluchea salicifolia

Porophyllum punctatum

Roldana albonervia

Roldana angulifolia Roldana barbajohannis

Rumfordia floribunda Simsia amplexicaulis Simsia lagasciformis Smallanthus maculatus

Tagetes erecta

Tagetes filifolia

Tithonia rotundifolia Tithonia tubiformis

Verbesina angustifolia

Verbesina sphaerocephala

Vernonia alamanii Viguiera dentata Xanthium strumarium Zinnia angustifolia Zinnia elegans

$\mathrm{X}$

X

x $\quad x$

$x$

X $\mathrm{X}$

X

$\mathrm{X}$

X

$x$

X

$\mathrm{X}$

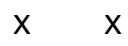

$\mathrm{X} X$

X

X
X

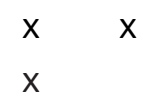

X

X

X

X

X $\quad x$

$x$ 
Appendix 3.

Ecological niche of 30 species of bee importance in the Lake Chapala and Duero river basins in Michoacán. The green area represents the potential distribution, the red points are the training records and the black points are the testing records. Yellow stars are new records found during field validation of models.

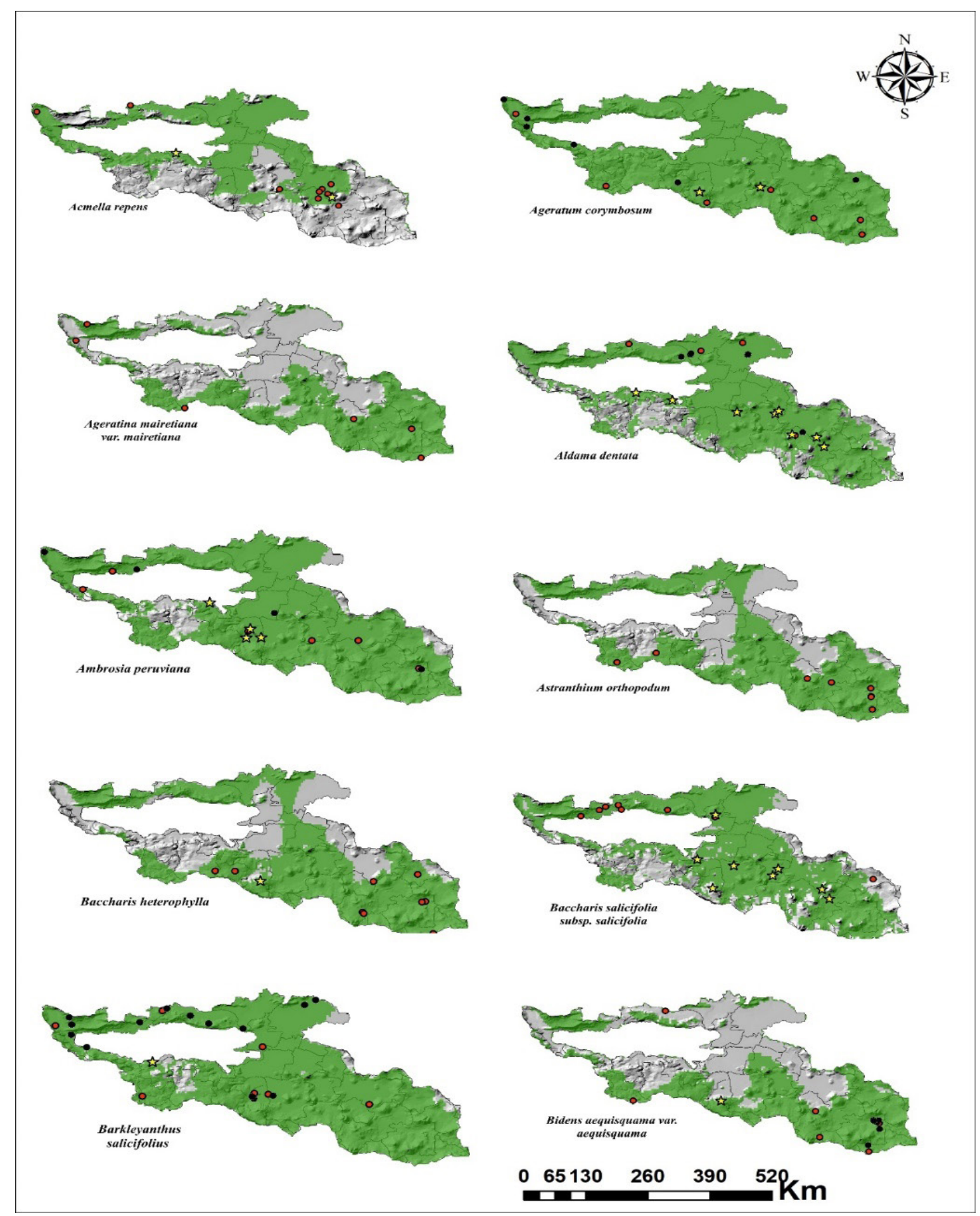




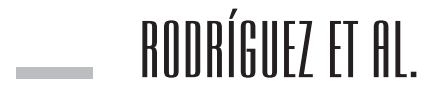

Niche models and apiary placement

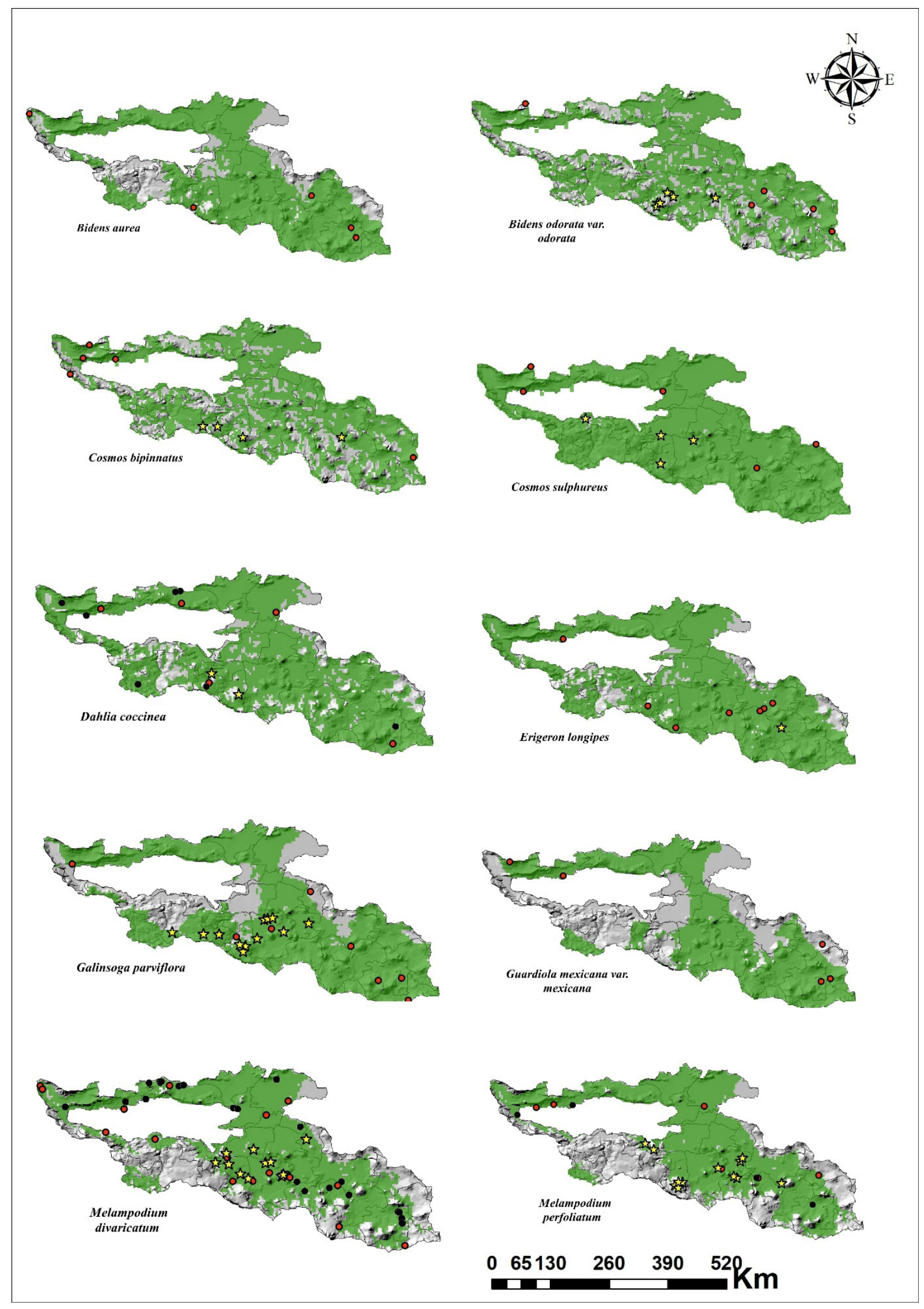

264 


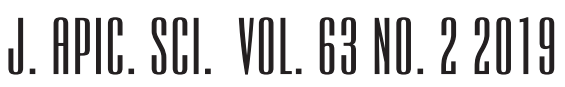

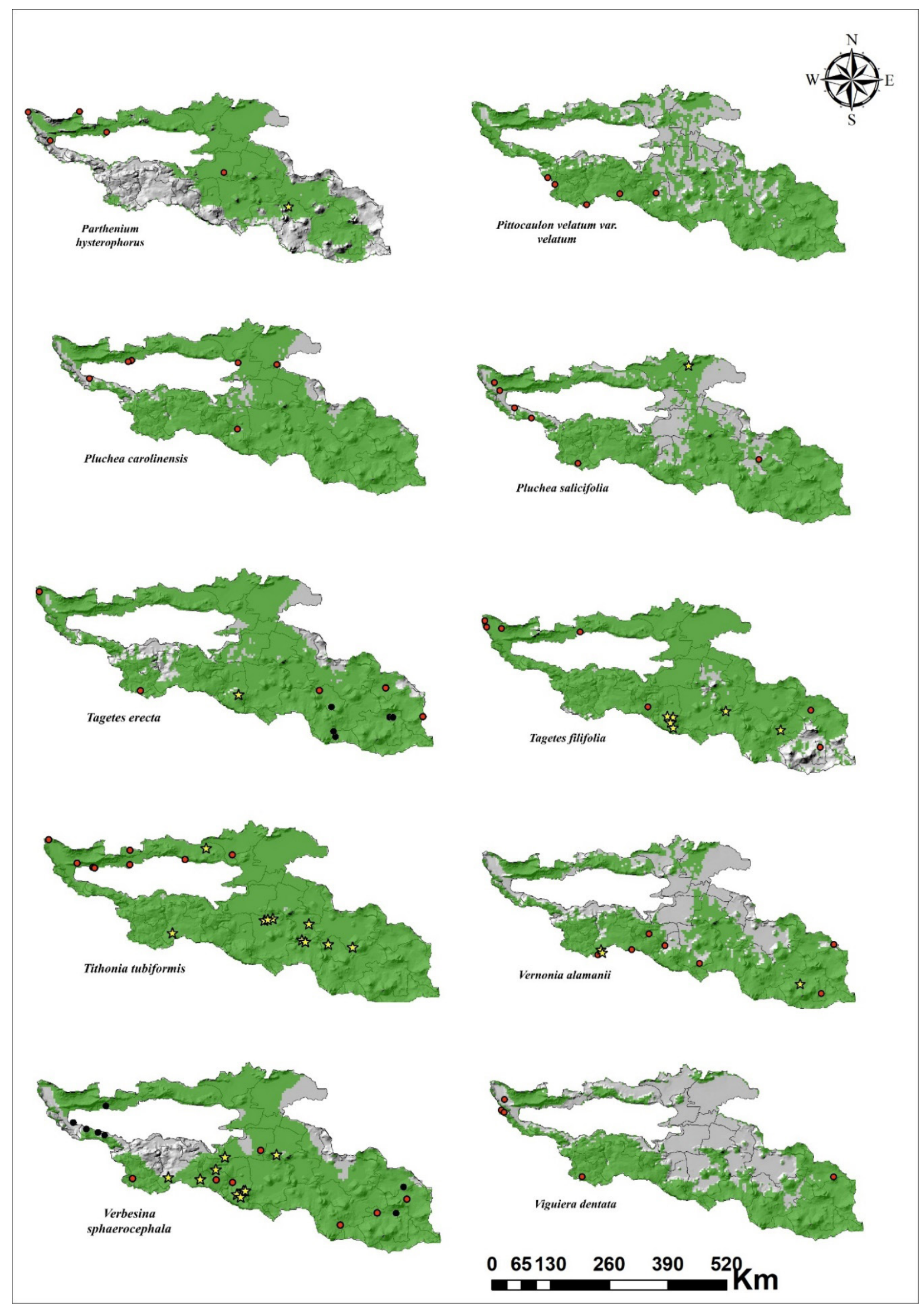

